\title{
Efficient isolation of high-quality RNA from lotus Nelumbo nucifera ssp nucifera tissues
}

\author{
Y.J. Zhang', X.Y. Hao ${ }^{1}$, Z.S. Liang ${ }^{1}$, W.D. $\mathrm{Ke}^{2}$ and H.B. Guo ${ }^{1}$ \\ ${ }^{1}$ Shaanxi Key Laboratory of Molecular Biology in Agriculture, \\ College of Life Sciences, Northwest A \& F University, Yangling, P.R. China \\ ${ }^{2}$ National Garden of Aquatic Vegetables, Wuhan Institute of Vegetable Science, \\ Wuhan, P.R. China
}

Corresponding author: H.B. Guo

E-mail: zouguoge@yahoo.com.cn

Genet. Mol. Res. 12 (1): 223-229 (2013)

Received May 10, 2012

Accepted November 28, 2012

Published January 24, 2013

DOI http://dx.doi.org/10.4238/2013.January.24.14

\begin{abstract}
Nelumbo nucifera is widely used as food, as an ornamental, in medicine, and as packing material; it is also reported to have anti-HIV effects and antioxidant capacity. We sought an improved method for extracting high-quality total RNA from different tissues of $N$. nucifera. Four methods for RNA extraction were assessed for their ability to recover high-quality RNA applicable for evaluation of polyphenol oxidase (PPO) gene expression profiles. The recovery and quality of the RNA obtained from five different tissues by the best CTAB-LiCl method were evaluated through UV light absorbance. Both $\mathrm{A}_{260} / \mathrm{A}_{280}$ and $\mathrm{A}_{260} / \mathrm{A}_{230}$ absorbance ratios were more than 2.0 ; the yield ranged from 59.87 to $163.75 \mu \mathrm{g} / \mathrm{g}$ fresh weight. The brightness of the $28 \mathrm{~S}$ band was approximately twice that of $18 \mathrm{~S}$; the latter was also considered as high-quality RNA. The PPO gene fragment (606 bp) was successfully amplified by RT-PCR, demonstrating the integrity of the isolated RNA. The relative expression levels of the PPO gene based on RT-PCR in five tissues of lotus were: rhizome buds (2.66), young leaves (2.42), fresh cut rhizome (2.02), petals (1.80), and petiole (1.65),
\end{abstract}


using housekeeping gene $\beta$-actin as an internal control. We concluded that the total RNA isolated by this protocol is of sufficient quality for molecular applications.

Key words: CTAB-LiCl; Gene expression; Nelumbo nucifera; RT-PCR; RNA isolation

\section{INTRODUCTION}

Lotus (Nelumbo nucifera Gaertn. ssp nucifera), identified as both food and traditional medicine by the Chinese government, is widely used as food, ornamental, medicine, and packing material in many countries (Guo et al., 2007; Guo, 2009). Recent studies have revealed that lotus has an anti-HIV effect due to the benzylisoquinoline alkaloids and flavonoids present in its leaves and shows an antioxidant capacity in different tissues (Kashiwada et al., 2005). These medicinal properties of lotus have attracted worldwide interest in pharmaceutical and genetic diversity research; however, investigation of the functional genes in this plant is limited. The limitation may be partially due to the presence of polysaccharides, polyphenols, flavonoids, and alkaloids in its tissues, which severely interfere with DNA, RNA and protein purification (Lönneborg and Jensen, 2000; Wang et al., 2012).

The previous plant RNA isolation protocols, including acidic guanidinium thiocyanate-based, SDS/phenol and hot borate methods, have proved unsuitable to isolate RNA when applied to tissues containing high levels of secondary metabolites (Xu et al., 2010; Wang et al., 2012). For RNA isolation from lotus, the large amounts of secondary metabolites mentioned above make it particularly difficult.

In this paper, we first describe a simple method to efficiently remove secondary metabolites from different tissues using the CTAB-LiCl method to obtain high-quality RNA, which showed good results in PCR and RT-PCR. Our methods made it possible to use various lotus tissues, namely young leaves, petiole, petals, freshly cut rhizome, and buds, under phenol-free conditions.

\section{MATERIAL AND METHODS}

\section{Plant materials}

Five tissues (young leaves, leaf petiole, petals, freshly cut rhizome, and buds) were collected from adult rhizome lotus of 'Elian 5' cultivar (for details, see Guo, 2009) in Xingping County, Shaanxi Province, China. Samples were cleaned and then snap-frozen in liquid $\mathrm{N}_{2}$ and stored at $-80^{\circ} \mathrm{C}$ before extraction.

\section{RNA extraction protocols}

Total RNA was isolated from three tissues (rhizome buds, stem and young leaves) of lotus by using four isolation methods, namely CTAB-LiCl, Trizol method (Qiagen, Beijing, China), RNAiso for polysaccharide-rich plant tissue kit (TaKaRa, Dalian, China), polysaccharide and polyphenol total RNA isolation kit (Biotake, Beijing, China). The last three isolation 
methods were carried out according to their corresponding commercial kit instructions. The $\mathrm{CTAB}-\mathrm{LiCl}$ method was performed as follows. In a pre-chilled mortar and pestle, $1 \mathrm{~g}$ freezedried tissue was finely ground using liquid nitrogen, and quickly transferred to $1 \mathrm{~mL}$ extraction buffer pre-warmed to $65^{\circ} \mathrm{C}$ for 5 min. RNA extraction buffer contained $2 \%(w / v) ~ C T A B, 2 \%$ (w/v) PVP, $100 \mathrm{mM}$ Tris-HCl, pH 8.0, 25 mM EDTA, pH 8.0, $2.0 \mathrm{M} \mathrm{NaCl}, 0.5 \mathrm{~g} / \mathrm{L}$ spermidine, and $2 \% \beta$-mercaptoethanol. The mixture was shaken vigorously for $15 \mathrm{~s}$ every $1 \mathrm{~min} 5-6$ times and then cooled down to room temperature. Chloroform, $1 \mathrm{~mL}$, was added and mixed well by inversion. The contents were centrifuged at $12,000 \mathrm{~g}$ for $20 \mathrm{~min}$ at $4^{\circ} \mathrm{C}$. To carefully collect the upper aqueous phase, an equal volume of chloroform was added and mixed well, followed by centrifugation at $12,000 \mathrm{~g}$ for $20 \mathrm{~min}$ at $4^{\circ} \mathrm{C}$. Exactly 0.25 volume $12 \mathrm{M} \mathrm{LiCl}$ was added to the upper aqueous phase and stored at $-20^{\circ} \mathrm{C}$ for one night after slight mixing. The mixture was centrifuged at $14,000 \mathrm{~g}$ for $20 \mathrm{~min}$ at $4^{\circ} \mathrm{C}$, the RNA pellet was resuspended in $500 \mu \mathrm{L}$ water treated with DEPC for $5 \mathrm{~min}$, and $500 \mu \mathrm{L}$ chloroform was added, followed by centrifugation at $14,000 \mathrm{~g}$ for $10 \mathrm{~min}$. Two volumes of ethanol were added to the collected upper phase. The pellet was collected by centrifugation $\left(12,000 \mathrm{~g}\right.$ for $20 \mathrm{~min}$ at $\left.4^{\circ} \mathrm{C}\right)$ after incubating the tubes at $-80^{\circ} \mathrm{C}$ for $2 \mathrm{~h}$ and then washed twice with $75 \%$ ethanol and centrifuged at $12,000 \mathrm{~g}$ for $10 \mathrm{~min}$ at $4{ }^{\circ} \mathrm{C}$. The pellet was resuspended in $30 \mu \mathrm{L} \mathrm{DEPC}$-treated water after evaporation of ethanol.

\section{Total RNA analysis}

The quality and quantity of total RNA were determined by monitoring the $\mathrm{A}_{260} / \mathrm{A}_{280}$ absorbance ratio using a UV-2802H spectrophotometer (Unico, Shanghai, China) and by $1.2 \%$ agarose gel electrophoresis.

\section{Cloning PCR products into T-vectors and sequencing}

The amplified polyphenol oxidase (PPO) gene fragment was cloned into PMD 19-T Vector (TaKaRa) as described by manufacturer instructions and the ligation product was used to transform DH-5a Escherichia coli. Clones carrying recombination plasmids were collected and sent to Shenggong, Shanghai, for sequencing.

\section{RT-PCR analysis}

First-strand cDNA was prepared using the Tianscript RT Kit (Tiangen, Beijing, China) in a one-tube protocol according to manufacturer instructions. The 606-bp cDNA of the PPO gene was transcribed using the specific primers designed from PPO cDNA as follows: forward (5'-TGATCGGAATGGAAGC-3') and reverse (5'-CAGCAATACCAGGGAAC-3'). PCR amplification was performed with $2 \mu \mathrm{g}$ first-strand cDNA, $1 \mathrm{X}$ buffer, $0.2 \mathrm{mM}$ dNTP mix, $0.2 \mu \mathrm{M}$ primer pair, and $0.25 \mathrm{U} / \mu \mathrm{L}$ Taq DNA polymerase. The amplification was as follows: $94^{\circ} \mathrm{C}$ for $2 \mathrm{~min}$, followed by 30 cycles of $94^{\circ} \mathrm{C}$ for $1 \mathrm{~min}, 60^{\circ} \mathrm{C}$ for $1 \mathrm{~min}$ and $72^{\circ} \mathrm{C}$ for $1.5 \mathrm{~min}$, and a final elongation step of $72^{\circ} \mathrm{C}$ for $10 \mathrm{~min}$. The PCR product of the expected size was obtained for the desired PPO cDNA as confirmed later by sequencing. The housekeeping gene $\beta$-actin was used as an internal control for the normalization of RNA quantity and quality differences between the tissues. The $\beta$-actin primers were: forward primer: 5'-TGATCGGAATGGAAGC3'; reverse primer: 5'-CAGCAATACCAGGGAAC-3'. For each tissue sample, the ratio ob- 
tained between the concentration values provided relative gene expression levels for the gene locus investigated.

\section{RESULTS AND DISCUSSION}

Three tissue (rhizome bud, leaf petiole and young leaves) samples were used to compare their RNA quality and quantity when isolated by four methods (Figure 1). The commonly used Trizol method produced brown pellets in our experiment, and the other two commercial kits or standard protocols were not efficient, which was also reported for other species containing greater amounts of secondary metabolites (Abbasi et al., 2010; Xu et al., 2010). The CTAB-LiCl method exhibited good quality and the brightness of the $28 \mathrm{~S}$ band was approximately twice that of $18 \mathrm{~S}$ (Figure 1), which was considered of high quality (Rosic and HoeghGuldberg, 2010). Dry lotus tissues of fresh young leaves, petiole, petals, freshly cut rhizome, and buds, which had been dried at $50^{\circ} \mathrm{C}$ in an oven to constant weight and then stored on silica gel, were also used to isolate RNA but proved to be unsuitable, although they could be used to extract DNA with the improved CTAB method (An et al., 2009).
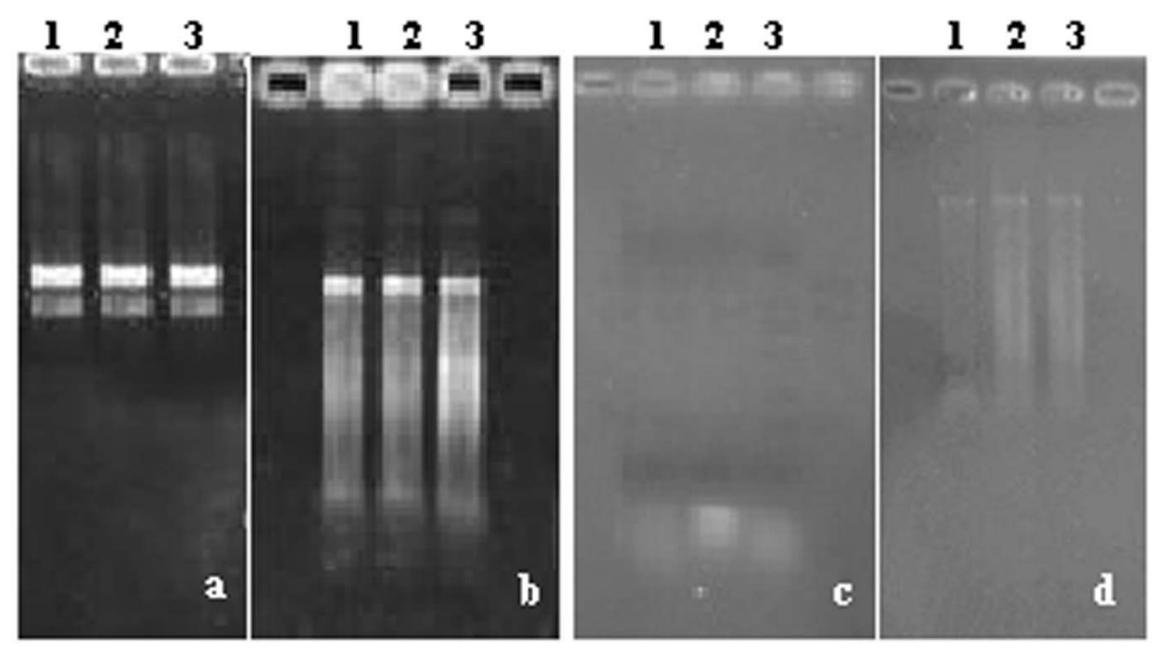

Figure 1. Four methods (a. CTAB-LiCl; b. RNAiso for polysaccharide-rich plant tissue kit; c. Trizol method; d. polysaccharide and polyphenol total RNA isolation kit) for RNA extraction from three tissues (lane 1 = rhizome buds; lane 2 = petiole; lane 3 = young leaves) of lotus (Nelumbo nucifera) were assessed and the brightness of $28 \mathrm{~S}$ RNA was twice than that of $18 \mathrm{~S}$ in three tissues when using the CTAB-LiCl method.

The improved protocol of CTAB-LiCl described here efficiently eliminated most of the secondary metabolites and produced white and water-soluble RNA precipitates with considerable yield (ranging from 59.87 to $163.75 \mu \mathrm{g} / \mathrm{g}$ fresh weight) (Table 1), which was compared to other species containing substantial amounts of secondary metabolites (Abbasi et al., 2010). In fact, CTAB-based methods have recently been used for nucleic acid isolation from polysaccharide-rich plants, and in particular, these methods have been used for RNA isolation (Thanh et al., 2009; Abbasi et al., 2010; Wang et al., 2012). Both $\mathrm{A}_{260} / \mathrm{A}_{230}$ and $\mathrm{A}_{260} / \mathrm{A}_{280}$ ratios were more 
than 2 suggesting that the RNA was of high purity and free of polysaccharide/polyphenol and protein contamination, respectively (Table 1) (Wang et al., 2005; Yang et al., 2011).

Table 1. Absorbance ratios and yield of total RNA isolated from five tissues of lotus (Nelumbo nucifera) with three replications by using the selected CTAB-LiCl method.

\begin{tabular}{|c|c|c|c|}
\hline Tissue & Mean $\mathrm{A}_{260} / \mathrm{A}_{280}$ ratio & Mean $\mathrm{A}_{260} / \mathrm{A}_{230}$ ratio & Yield ( $\mu \mathrm{g} / \mathrm{g}$ fresh weight) \\
\hline Rhizome buds & $2.03 \pm 0.02$ & $2.27 \pm 0.01$ & $163.75 \pm 0.05$ \\
\hline Young leaves & $2.02 \pm 0.02$ & $2.32 \pm 0.02$ & $132.21 \pm 0.02$ \\
\hline Petals & $2.04 \pm 0.01$ & $2.28 \pm 0.02$ & $97.75 \pm 0.03$ \\
\hline Young petiole & $2.03 \pm 0.01$ & $2.25 \pm 0.02$ & $73.70 \pm 0.04$ \\
\hline Fresh cut rhizome & $2.05 \pm 0.02$ & $2.30 \pm 0.07$ & $59.87 \pm 0.08$ \\
\hline
\end{tabular}

To evaluate the suitability of the isolated RNA in downstream molecular procedures, total RNA was used for RT-PCR and PPO gene cloning. Due to the high sensitivity of reverse transcription to impurities, it is of utmost importance to produce pure RNA for successful construction of full-length cDNA libraries and determination of gene expression. The PPO gene fragment (606 bp) was first and successfully amplified (Figure 2) and compared with GenBank data after being sequenced. High homology through alignment confirmed the identity of the RT-PCR product after the full-length cDNA was sequenced by RACE (data not shown).

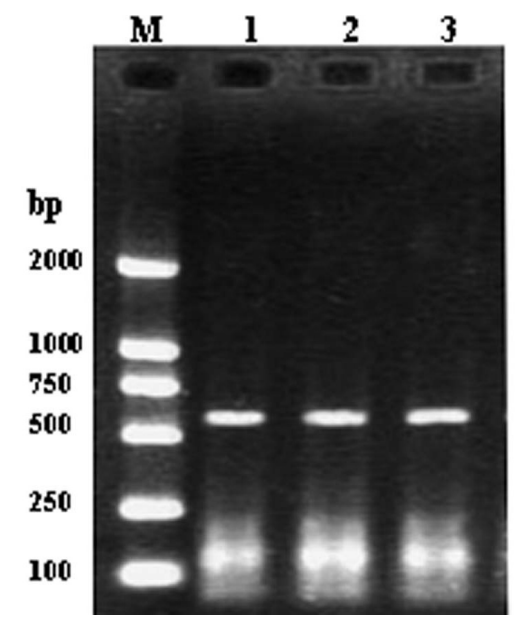

Figure 2. The polyphenol oxidase gene fragment (606 bp) was successfully amplified from three tissues (lane $1=$ rhizome buds; lane 2 = petiole; lane 3 = young leaves; lane $M=$ molecular marker) of lotus (Nelumbo nucifera) by RT-PCR.

RNA isolated from different tissues of lotus was used in the determination of PPO gene expression, using the $\beta$-actin gene as internal control. The results showed that the actin gene was stably and entirely expressed in five tissues (young leaves, petiole, petals, fresh cut rhizome, and rhizome buds) (Figure 3), and the relative expression levels of the PPO gene were determined in the five tissues: rhizome buds (2.66), young leaves (2.42), fresh cut rhizome (2.02), petals (1.80), and petiole (1.65) (Figure 3). 


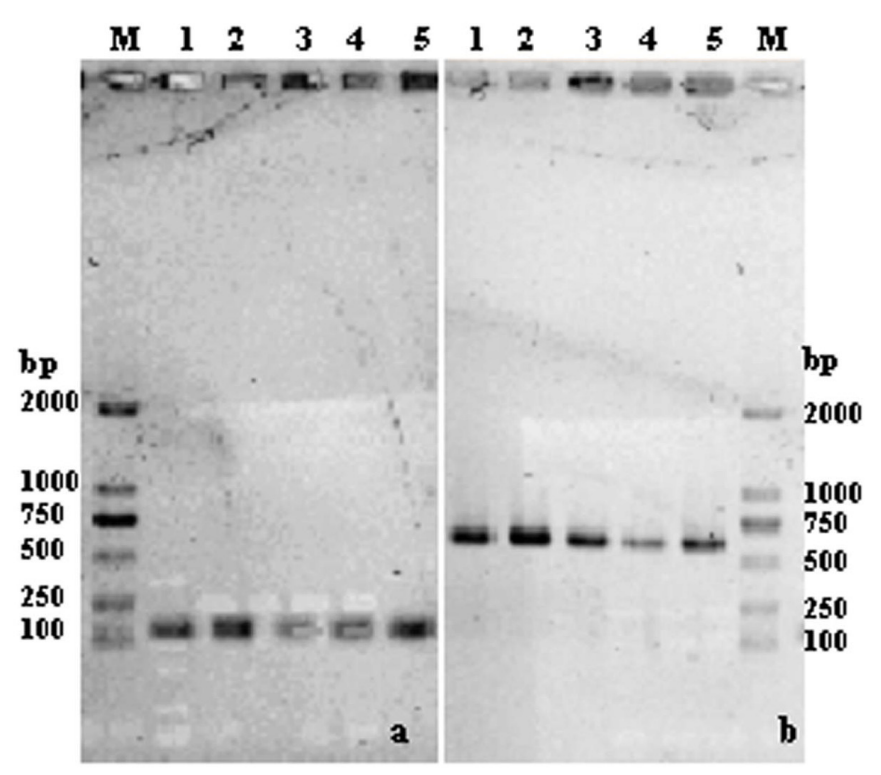

Figure 3. Relative expression levels of the polyphenol oxidase (PPO) gene in five tissues (lane 1 = petals; lane 2 = fresh cut rhizome; lane 3 = rhizome buds; lane 4 = petiole; lane $5=$ young leaves; lane $M=$ molecular marker) of lotus (Nelumbo nucifera) were determined by RT-PCR using $\beta$-actin as internal control. a. $\beta$-actin fragments; $\mathbf{b}$. PPO gene fragments.

\section{CONCLUSION}

The proposed protocol proved to be efficient and suitable for the isolation of high-quality RNA from five tissues (rhizome bud, petiole, petal, cut rhizome, and leaves) of lotus, a medicinal plant that contains large amounts of secondary metabolites (polyphenols, polysaccharides and alkaloids) in different tissues. The total RNA isolated using the CTAB-LiCl method was of high integrity, purity and yield and was suitable for downstream molecular assays.

\section{ACKNOWLEDGMENTS}

Research supported by the China Education Ministry National Higher Education Fund for Doctoral Program (\#20100204120027) and Science and Technology Department of Shaanxi Government (\#2011K01-18).

\section{REFERENCES}

Abbasi KA, Hosseini Tafreshi SA, Khayyam Nekouei SM and Mofid MR (2010). Efficient isolation of high quality nucleic acids from different tissues of Taxus baccata L. Mol. Biol. Rep. 37: 797-800.

An N, Guo HB and Ke WD (2009). Genetic variation in rhizome lotus (Nelumbo nucifera Gaertn. ssp. nucifera) germplasms from China assessed by RAPD markers. Agric. Sci. China 8: 31-39.

Guo HB (2009). Cultivation of lotus (Nelumbo nucifera Gaertn. ssp. nucifera) and its utilization in China. Genet. Resour. Crop Evol. 56: 323-330. 
Guo HB, Li SM, Peng J and Ke WD (2007). Genetic diversity of Nelumbo accessions revealed by RAPD. Genet. Resour. Crop Evol. 54: 741-748.

Kashiwada Y, Aoshima A, Ikeshiro Y, Chen YP, et al. (2005). Anti-HIV benzylisoquinoline alkaloids and flavonoids from the leaves of Nelumbo nucifera, and structure-activity correlations with related alkaloids. Bioorg. Med. Chem. 13: $443-448$.

Lönneborg A and Jensen M (2000). Reliable and reproducible method to extract high-quality RNA from plant tissues rich in secondary metabolites. Biotechniques 29: 714, 716-714, 718.

Rosic NN and Hoegh-Guldberg O (2010). A method for extracting a high-quality RNA from Symbiodinium sp. J. Appl. Phycol. 22: 146.

Thanh T, Omar H, Abdullah MP, Chi VT, et al. (2009). Rapid and effective method of RNA isolation from green microalga Ankistrodesmus convolutus. Mol. Biotechnol. 43: 148-153.

Wang G, Wang G, Zhang X, Wang F, et al. (2012). Isolation of high quality RNA from cereal seeds containing high levels of starch. Phytochem. Anal. 23: 159-163.

Wang T, Zhang N and Du L (2005). Isolation of RNA of high quality and yield from Ginkgo biloba leaves. Biotechnol. Lett. 27: 629-633.

Xu J, Aileni M, Abbagani S and Zhang P (2010). A reliable and efficient method for total rna isolation from various members of spurge family (Euphorbiaceae). Phytochem. Anal. 21: 395-398.

Yang F, Tan H, Zhou Y, Lin X, et al. (2011). High-quality RNA preparation from Rhodosporidium toruloides and cDNA library construction therewith. Mol. Biotechnol. 47: 144-151. 